\title{
Correction: Estimation of injury costs: financial damage of English Premier League teams' underachievement due to injuries
}

Eliakim E, Morgulev E, Lidor R, et al. Estimation of injury costs: financial damage of English Premier League teams' underachievement due to injuries. BMJ Open Sport $\mathcal{E}$ Exercise Medicine 2020;6:e000675. doi:10.1136/bmjsem-2019-000675.

The article has been corrected since it was published online. The authors want to alert the readers to the following errors identified in the published version. The "Competing interests" statement has been updated as well.

In the Results section of the abstract, the first sentence should read "We found a statistically significant relationship $(\mathrm{r}=-0.46,95 \% \mathrm{CI}-0.6$ to $-0.28, \mathrm{p}=0.001) \ldots$ ”

In the "Results" section at page 3 , the first sentences of the third and fifth paragraph should read as

"In figure 1, a statistically significant relationship ( $\mathrm{r}=-0.46,95 \% \mathrm{CI}-0.6$ to -0.28 , $\mathrm{p}<0.0001) \ldots "$

"Figure 2 displays the statistically significant relationship ( $\mathrm{r}=-0.38,95 \%$ CI -0.54 to $-0.2, \mathrm{p}=0.001) \ldots "$

Competing interests EE is the current CTO and co-founder of "Zone7", a company that uses artificial intelligence to develop injury prevention solutions. EM, RL and YM declare that they have no conflict of interest.

Open access This is an open access article distributed in accordance with the Creative Commons Attribution Non Commercial (CC BY-NC 4.0) license, which permits others to distribute, remix, adapt, build upon this work non-commercially, and license their derivative works on different terms, provided the original work is properly cited, appropriate credit is given, any changes made indicated, and the use is non-commercial. See: http://creativecommons.org/licenses/by-nc/4.0/.

(C) Author(s) (or their employer(s)) 2020. Re-use permitted under CC BY-NC. No commercial re-use. See rights and permissions. Published by BMJ.

BMJ Open Sp Ex Med 2020;6:e00675corr1. doi:10.1136/bmjsem-2019-000675corr1

Check for updates 